\title{
Geochemical evidence for the tectonic setting of early Proterozoic metavolcanic sequences in southern Lake Superior region
}

\author{
Wee, Soo Meen* \\ Department of Earth Sciences, Korea National University of Education \\ Cheongwon. Choongbook 363-791, Korea
}

\begin{abstract}
Samples of metabasaltic dikes and lavas from early Proterozoic rock units in the southcentral Lake Superior region were analyzed for major and selected trace elements in order to compare their chemical composition with those of rocks from modern, known tectonic environments. The rocks exhibit a relatively wide compositional range in which the least evolved samples show a chemical composition similar to that of T-type MORB.

Based on geochemical characteristics and tectonic discrimination diagrams, I conclude that the rock suites were emplaced in an extensional regime. The geochemical patterns of these rocks are similar to those of British Tertiary Volcanic Province and continental tholeiitic basalts from Edendeka, which erupted in more recent rift environments.
\end{abstract}

Keywords: Tectonostratigraphic terrane, Crustal contamination, Immobile element, Continental flood basalt, Ocean island basalt, Calc-alkaline basalt

\section{Introduction}

Two major early Proterozoic tectonic provinces in the southern Lake Superior region, the northern passive margin terrane and the southern magmatic arc complex (Fig. 1), have given rise to controversial interpretations of their tectonic evolution (Sims, 1976; Van Schmus, 1976 ; Cambray, 1977, 1978; Larue and Sloss, 1980; Hoffman, 1988). Studies have suggested that the northern passive margin terrane was subducted below and accreted to the southern magmatic arc terrane during the Penokean Orogeny about $1.85-1.9 \mathrm{Ga}$ (Cam. bray, 1977, 1978; Larue and Sloss, 1980 ; Larue and Ceng, 1985). However, Van Schmus (1976) proposed that the deformed and metamorphosed northern terrane represents a deformed back-arc or foreland basin assemblage and that the arc terrane is a remnant of a
Proterozoic Andean type continental margin. The Penokean Orogeny has also been interpreted to be a result of vertical remobilization of intracratonic basement (Sims, 1976, 1980; Klasner, 1978).

The early Proterozoic Hemlock volcanics, which are a part of a passive margin terrane, and the Badwater greenstones of the Crystal Falls terrane represent a volcanic and intrusive stage in the formation of this geologically complex area within craton. The widespread intrusion of the early Proterozoic dikes within the study area probably took place during this stage and served as feeders to one or both of the volcanic piles. It has been recognized that volcanic rocks erupted within specific tectonic settings possess distinctive trace element and, in some cases, major element signatures.

In spite of their great age, early Proterozoic rocks may still retain many of their origi- 


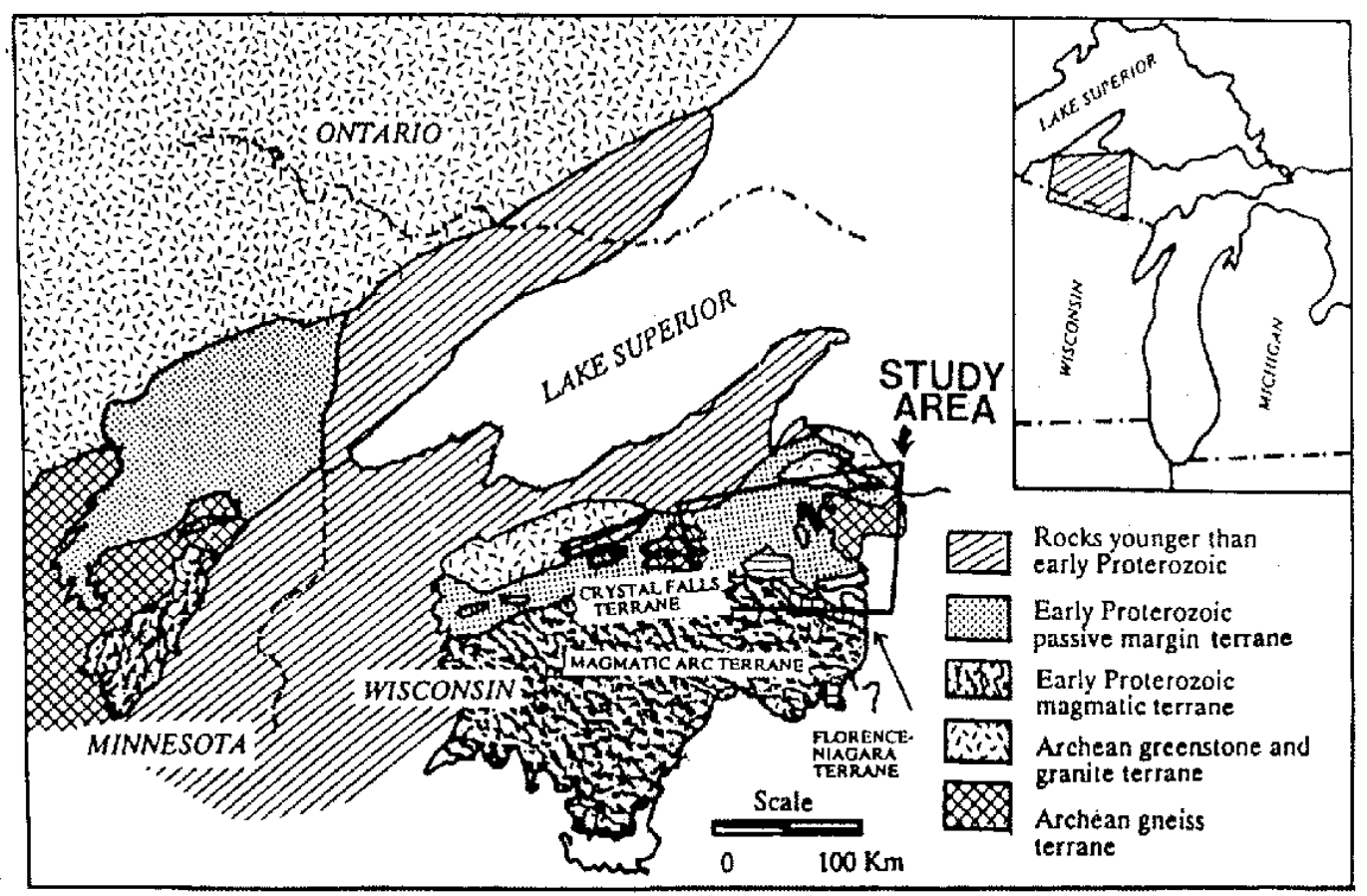

Fig. 1. Early Proterozoic tectonostratigraphic terranes in the southern Lake Superior region.

nal chemical characteristics. Previous studies of the dike swarms are few and can not be used to evaluate petrochemical variations within the swarms, either temporally and spatially. Thus, more data were required before reasonable petrogenetic/tectonic interpretations could be made for this stage of development of the North America craton.

The major objective of this paper is to analyze and evaluate the petrochemistry of the early Proterozoic intrusive dike swarms and basaltic lava flows in order to establish the petrogenetic origin of the rock suites to determine whether the tectonic environment was suboceanic or subcontinental and whether it was subduction related or rift related.

\section{Regional geology}

The Precambrian geology of northern Michigan and northeastern Wisconsin is very complex and is related to several tectonic events. The area has been involved in two major orogenic episodes, the Algoman Orogeny (2.7 Ga) and the Penokean Orogeny, which occurred about $1.85-1.9 \mathrm{Ga}$ and included deformation, regional metamorphism, and extrusive and intrusive igneous activities (Cannon, 1973; Van Schmus, 1976).

The area has been divided into four tectonostratigraphic terranes by Larue (1983). The terranes are 1) the passive margin terrane, 2) the Crystal Falls terrane, 3) the Florence-Niagara terrane, and 4) the northern Wisconsin magmatic arc terrane (Fig. 1).

The passive margin terrane is composed of three transgressive metasedimentary sequences deposited unconformably on Archean sialic crust. The metasedimentary sequence, from the oldest to youngest, are the Chocolay, the Menominee and the Baraga Groups. The Chocolay Group has characteristics in common with a modern miogeosynclinal or shelf sea facies association (Cambray, 1978). Larue and Sloss (1980) suggested that the Chocolay 


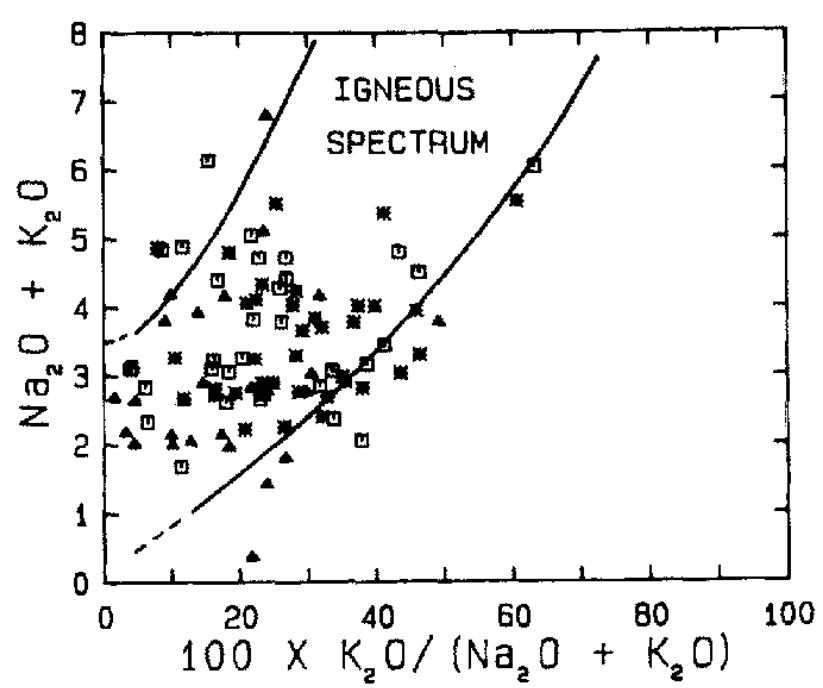

* Dikes

$\triangle$ B.W. Greenstones

(] Hemlack Volcanics

Fig. 2. Studied rock suites on a $\left(\mathrm{Na}_{2} \mathrm{O}+\mathrm{K}_{2} \mathrm{O}\right)$ vs. $100 \mathrm{~K}_{2} \mathrm{O} /\left(\mathrm{Na}_{2} \mathrm{O}+\mathrm{K}_{2} \mathrm{O}\right)$ diagram. Igneous spectrum (area between solid lines) represents the range of variation of modern volcanic rocks.

Group sediments accumulated in elongated basins and on platforms between the basins. The tectonic conditions were apparently relatively stable during the deposition of Chocolay Group strata. The Menominee Group is a fining upward sequence with a basal quartzite overlain by laminated argillites, and chemical precipitates with local conglomerates. It was deposited unconformably on the lower Precambrian basement rocks with mild tectonic disturbances during sedimentation (Van Schmus, 1976; Cambray, 1978). An extensive period of erosion seems to have occurred before the first formation of Baraga Group was laid down (Cambray, 1978). The Baraga Group is composed of a basal quartzite, an iron formation, and the tholeiitic basalts of the Hemlock Formation, followed by deposition of turbidites of the Michigamme slate (James et al., 1968; Larue and Sloss, 1980). The composition of these volcanic rocks change from felsic in the northeast to mafic to the southwest (Cannon and Klasner, 1976) and several differentiated intrusives (e.g., Kiernan Sills, and the mafic plutonic stock complex at Pevey Pond) were emplaced into the Hemlock Formation (Fox, 1983).

The Crystal Falls terrane is composed of the Paint River Group and the underlying Badwater greenstones, a thick unit of pillow basalts and greenstones. The contact of Paint River Group with the underlying Badwater greenstone has been inferred to be a fault along the northern border of the Crystal Falls terrane (Larue, 1983), or an unconformity (James et al., 1968).

The elongated, fault-bounded FlorenceNiagara terrane consists of at least eight faultbounded packets containing highly deformed rocks that are, for the most part, correlative with the passive margin terrane (Larue, 1983). The Florence-Niagara terrane has been interpreted as a fragment of the passive margin terrane which was accreted to the forearc area of the magmatic terrane during the Penokean arc-continent collision (Larue and Ueng, 1985).

The magmatic arc terrane consists of several cores of granitoid to gneissic rocks mantled by highly deformed metavolcanic, metapelitic, and metagabbroic rocks. This area shows a 


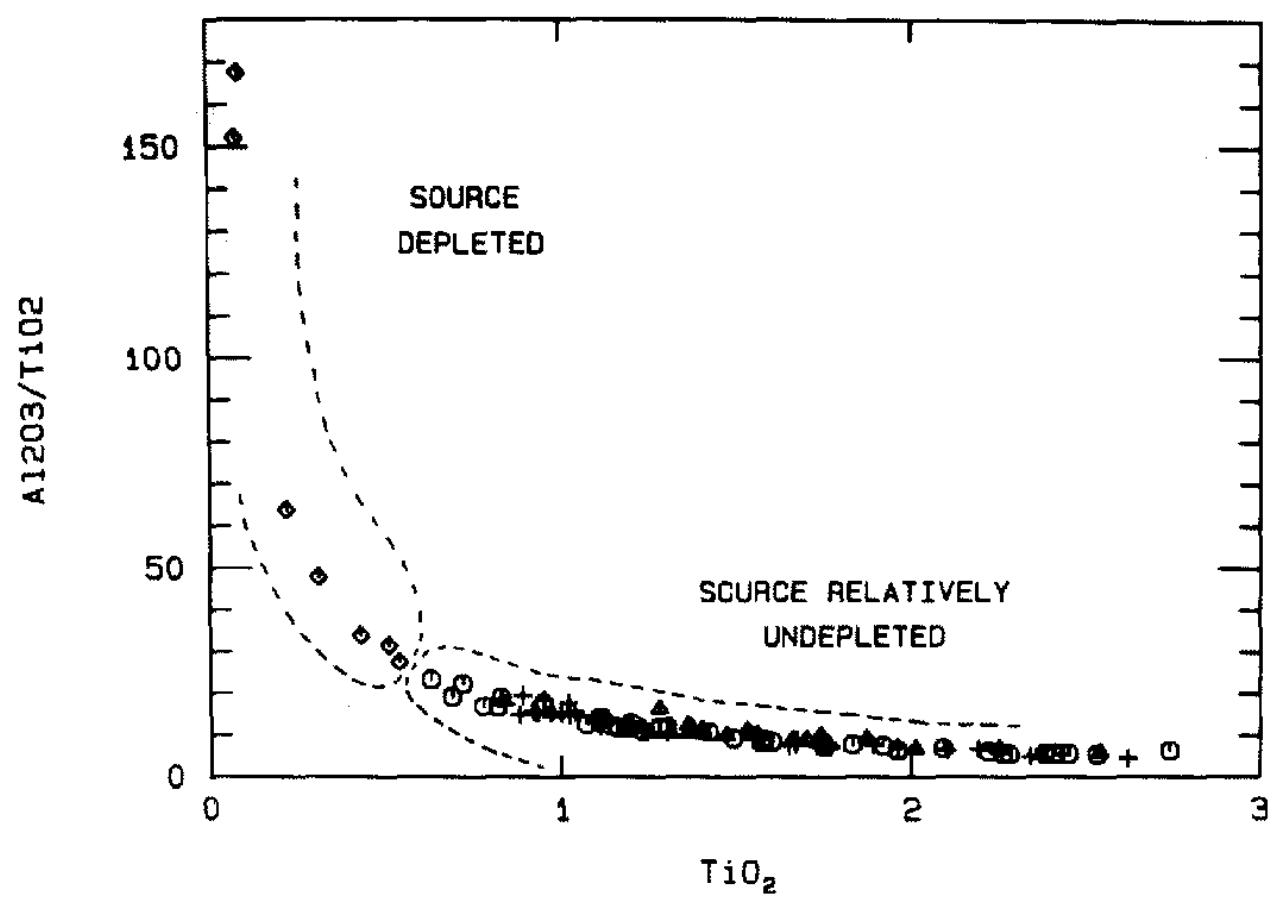

Fig. 3. Diagrams using $\mathrm{TiO}_{2}$ to detect degree of depletion in the magma source (Sun and Nesbitt, 1978). Most of the rocks of the Quinnesec Formation (diamond, data from Cudzilo, 1978) reside in the area marked for arc volcanism, indicating they originated from partial melting of residual mantle. The dikes (open circles with dots), Hemlock volcanics (crosses), and Badwater greenstones (triangles), on the other hand, seem to have come from less depleted mantle sources.

record that records a major interval of calcalkaline and tholeitic volcanism at $1.86-1.87 \mathrm{Ga}$ (Sims, 1988).

Dike swarms are exposed mostly in the northern passive margin terrane with various orientations. Basaltic dikes were intruded into the Archean basement and early Protetozoic metasedimentary sequences. Cannon (1973) proposed that these dikes were probably emplaced in the Baraga Group as an equivalent to the basaltic lavas. Although the exact relative age of any individual dike is indeterminate, some dikes, if not most, have been interpreted as predating the Penokean Orogeny (Baxter and Bornhorst, 1988).

The causes of the tectonic activity of the Penokean Orogeny have been variously interpreted by previous workers. Van Schmus
(1976) interpreted the Chocolay and Menominee Groups as possibly indicating passive margin deposition, whereas the Baraga Group strata were deposited in a foreland basin. He tentatively modelled the Penokean Orogeny as a product of a consuming continen. tal margin, with ocean floor (to the south) subducted toward the north.

The rifting model was proposed by Cam. bray (1978). This model proposed that the Chocolay Group was deposited in a cratonic setting and that the strata of the Menominee Group show features which are inferred to indicate initiation of rifting. In this model, the Penokean Orogeny was caused by the collision of a continent to the north with an arc to the south. The deformation in the Penokean Orogeny was produced by horizontal compres. 


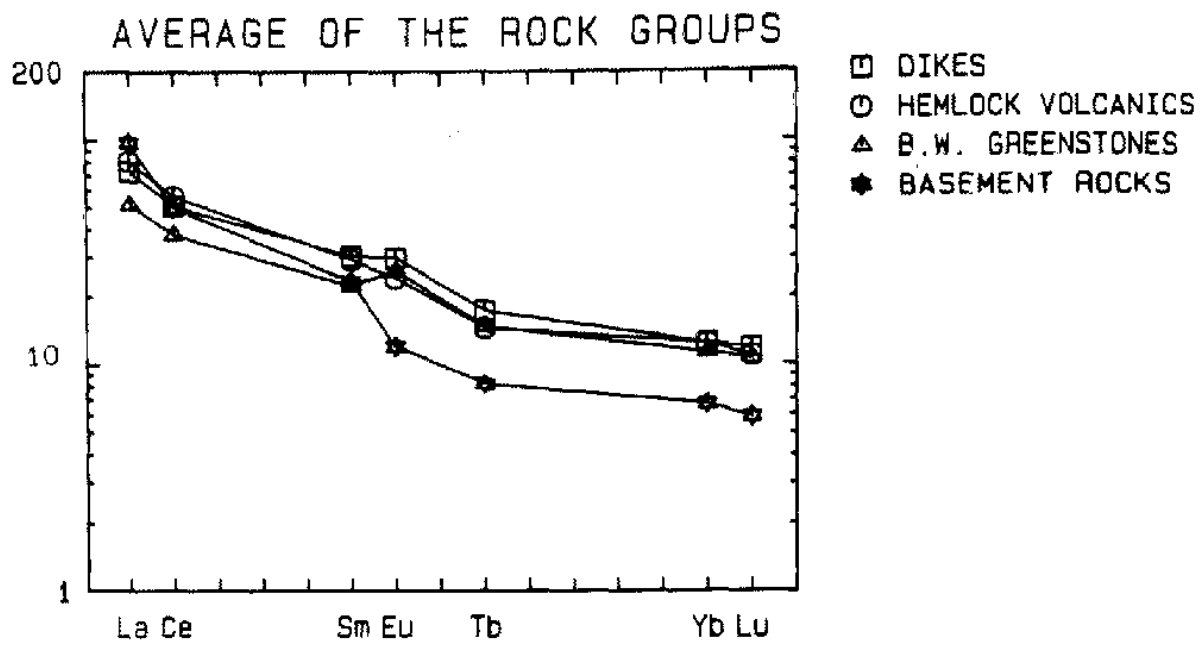

Fig. 4. Chondrite normalized REE patterns for the averages of the studied rock suites. For comparison, averaged basement rocks are presented (data from Wee, 1989 and Ueng et al, 1988). Normalizing factors and arrangement of elements are based on Thompson (1982).

sion and was transmitted from the basement to the folded cover rocks by ductile shear in the basement following collision (Cambray, 1984). This collision terminated intraplate rifting and associated volcanism on northern plate.

The early Proterozoic tectonic evolution of the southern Lake Superior region has been alternatively interpreted by a foredeep model (Hoffman, 1988). Foredeeps are linear asymmetric basins that migrate in front of, and become incorporated within, foreland thrust fold belts. They develop as a flexural response to loading of the continental lithosphere by thrust sheets.

\section{Sampling and analytical methods}

This study focused on the early Proterozoic dikes and volcanic piles (Hemlock vol. canics and Badwater greenstones) in northern Michigan and northeastern Wisconsin. Forty four dikes, forty Hemlock volcanics from the passive margin terrane and twenty nine sam. ples of the Badwater greenstone from the Crys. tal Falls terrane were studied. Another 10 samples collected from the granitic basement rocks were measured for major, trace and REE to verify the possible source of magmatic contaminent of the studied rocks. All the sam. ples analyzed are metamorphosed to grade up to greenschist facies.

The whole rock samples were analyzed for major and selected trace elements, including rare earth elements (REE). Major elements were determined by XRF using glass waffles and trace elements $\mathrm{Rb}, \mathrm{Sr}, \mathrm{Nb}, \mathrm{Y}, \mathrm{Ni}, \mathrm{Cu}, \mathrm{Zn}$, $\mathrm{Zr}$, and $\mathrm{Y}$ were also determined by $\mathrm{XRF}$, using pressed powder pellets. REE and $\mathrm{C}, \mathrm{Th}, \mathrm{Sc}$ and Hf were determined by INAA.

Precision for major elements is better than $2 \%$ except for $\mathrm{P}$, which is $5.4 \%$. Trace elements data by XRF are precise to within $5 \%$ except for $\mathrm{Y}$ and $\mathrm{Zn}$, which are less than $10 \%$. Precision for elements by INAA is better than $10 \%$, but where concentrations are less than 10 ppm ( $\mathrm{Tb}, \mathrm{Lu}$, and $\mathrm{Th}$ ), precision approaches $15 \%$.

\section{Analytical results}

\section{Major elements}

The dikes and lava flows have mostly basaltic compositions with a relatively wide range of $\mathrm{SiO}_{2}(43-60 \%)$ and are quartz, or less 


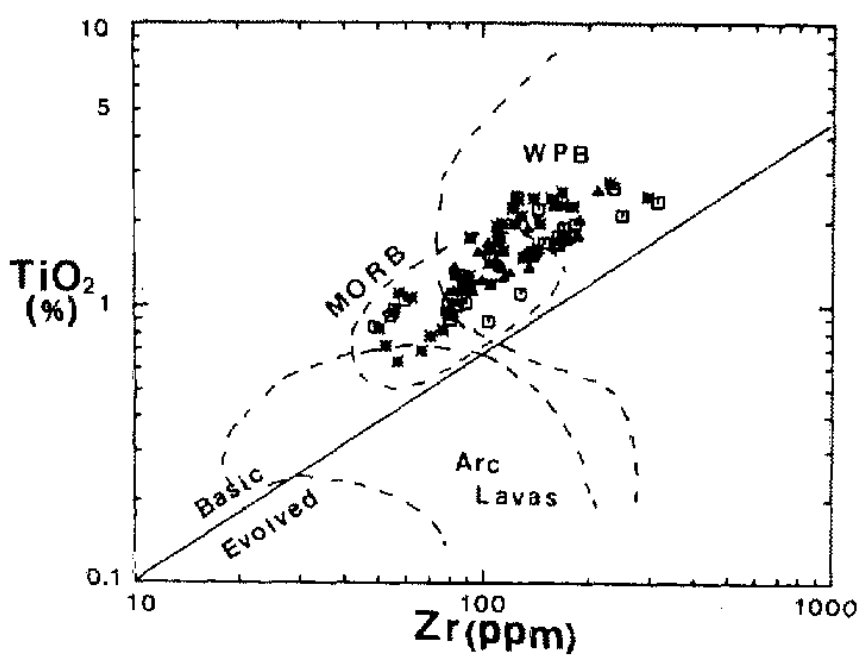

* Dikes

$\Delta$ B.H. Greenstones

(D) Hemlock Volcanlcs

Fig. 5. Plot of $\mathrm{TiO}_{2}$ vs. $\mathrm{Zr}$ for the dikes, the Hemlock volcanics, and the Badwater greenstones. MORB, within plate (WPB), and arc-volcanic field locations are taken from Pharaoh and Pearce (1984).

commonly, olivine normative. A few samples are nepheline normative, possibly caused by the addition of $\mathrm{Na}$ and $\mathrm{K}$ during hydrothermal alteration or metamorphic recrystallization (Knoper and Condie, 1988). The dikes and volcanic piles are tholeitic and no alkalic basalts were found (Wee, 1989). The absence of alkalic basalts within the region means that early Proterozoic magmas were generated at relatively shallow depths, possibly under the influence of a high geothermal gradient.

Fig. 2 shows the results plotted on a $\left(\mathrm{Na}_{2} \mathrm{O}+\mathrm{K}_{2} \mathrm{O}\right)$ versus $100 \mathrm{~K}_{2} \mathrm{O} /\left(\mathrm{K}_{2} \mathrm{O}+\mathrm{Na}_{2} \mathrm{O}\right)$ diagram which is useful to evaluate the effects of secondary alteration by using the most mobil elements (Hughes, 1973). Rock compositions lie outside the envelope ("igneous spectrum") are probably due to element mobility during secondary alteration (Honkamo, 1987). Although the diagram shows a few samples outside this envelope, most fall well within the field of modern volcanic suites, suggesting that metamorphic alteration might have been minimal.

Fig. 3 shows the $\mathrm{Al}_{2} \mathrm{O}_{3} / \mathrm{TiO}_{2}$ plot of the rocks from the magmatic arc terrane (data from Cudzilo, 1978) and studied samples. The low-Ti calc-alkaline rocks from the magmatic arc terrane have extremely high $\mathrm{Al}_{2} \mathrm{O}_{3} / \mathrm{TiO}_{2}$ ratio whereas the studied samples are relatively high in $\mathrm{TiO}_{2}$ and lower $\mathrm{Al}_{2} \mathrm{O}_{3} / \mathrm{TiO}_{2}$ ratio. The studied Proterozoic rocks are suggested from Fig. 3 not to have formed in an island arc environment. Average chemical compositions of the investigated rocks are listed in Table.

\section{Trace and rare earth elements}

The averaged REE concentrations normalized to chondrite values of Thompson (1982) are illustrated in Fig. 4. For comparison, an average analysis of the granitic basement rocks sampled throughout the region are also presented. The dike swarms, Hemlock volcanics, and the Badwater greenstones show very similar REE pattern and all exhibit LREE enrichment (e.g., $[\mathrm{Ce} / \mathrm{Yb}]_{\mathrm{c}}=0.99-9.38, \mathrm{c}$ : chondrite normalization). A few greenstone samples show Ce depletions which might be caused by sea water interaction (Henderson, 1984). The similar REE patterns of these rock suites may support the result of the previous study (Wee, 


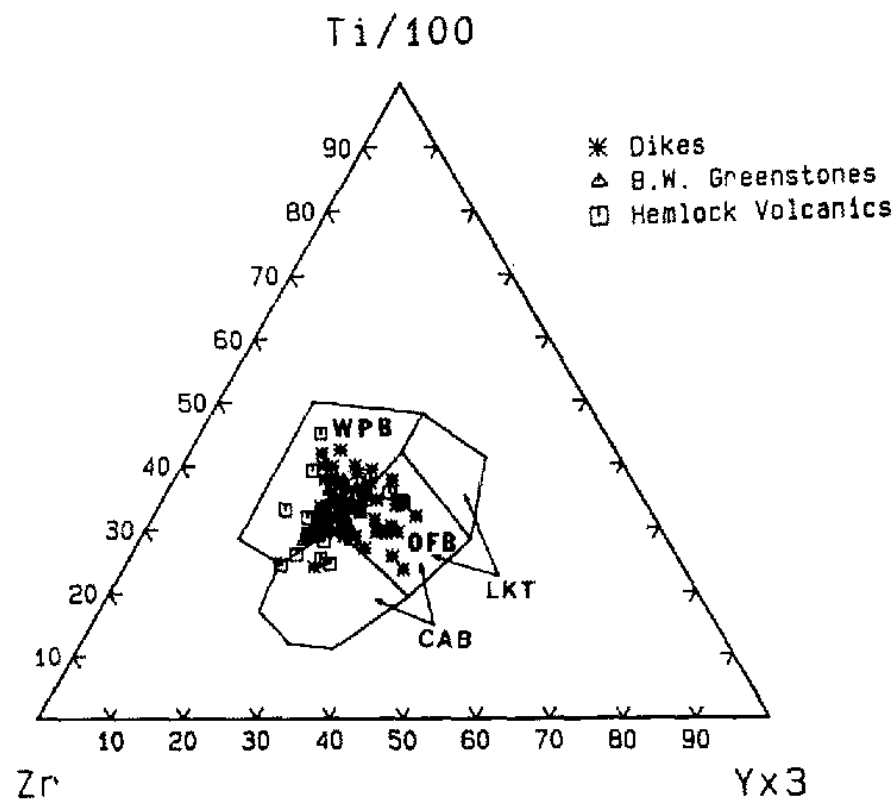

Fig. 6. Ti-Zr-Y diagram. Locations of basalt field are taken from Pearce and Cann (1973). WPB, within plate (intraplate) basalts; $L K T$, low-K tholeiitic basalts; OFB, ocean floor basalts; $\mathrm{CAB}$, calc-alkaline basalts.

1992) which revealed that the rock suites were generated from same magma source.

Spider diagrams for averages of the dike swarms, Hemlock volcanics, Badwater greenstones, and basement rocks are shown in Fig. 10a. These groups show enrichment of the large ion lithophile (LL) elements relative to the other incompatible elements. These hygromagmatophile element patterns are very distinct from that of modern N-MORB, but closely comparable to calc-alkaline basalts from continental margins and E-type MORB (except in $\mathrm{Nb}$ in the latter), which are enriched in incompatible elements and LREE relative to HREE.

\section{Geochemical interpretations of tectonic setting}

A major problem in interpreting the element abundances in the metamorphic rocks is elemental migration. The rock suites of the study area have been homogeneously metamor- phosed to greenschist facies except for the south of Amasa Oval (located in south east corner of the study area), where metamorphism reaches amphibolite facies. However, it has been widely accepted that the elements $\mathrm{Ti}, \mathrm{P}$, $\mathrm{Zr}, \mathrm{Hf}, \mathrm{Ta}, \mathrm{Sc}, \mathrm{Nb}, \mathrm{Y}$, and HREE's in basalts are resistant to alteration and metamorphism (Cann, 1970; Pearce and Cann, 1973; Floyd and Winchester, 1975; Ferrara et al., 1976; Wood et al., 1976; Ludden and Thompson, 1978; Muecke et al., 1979 ; Pearce and Norry, 1979 ; Ludden et al., 1982) and we call them immobile elements, while other elements such as $\mathrm{Sr}, \mathrm{Ca}, \mathrm{Ba}, \mathrm{K}$, and $\mathrm{Na}$ have been shown to be mobile even during low grade alteration by Humphris and Thompson (1978), Gelinas et al. (1982), and Ludden et al. (1982). The LIL elements of the studied rock suites show a scattering and poorer correlation as compared to the tight clustering of the immobile elements (Wee, 1989). This suggests that the immobile elements can be used for discrimination dia- 


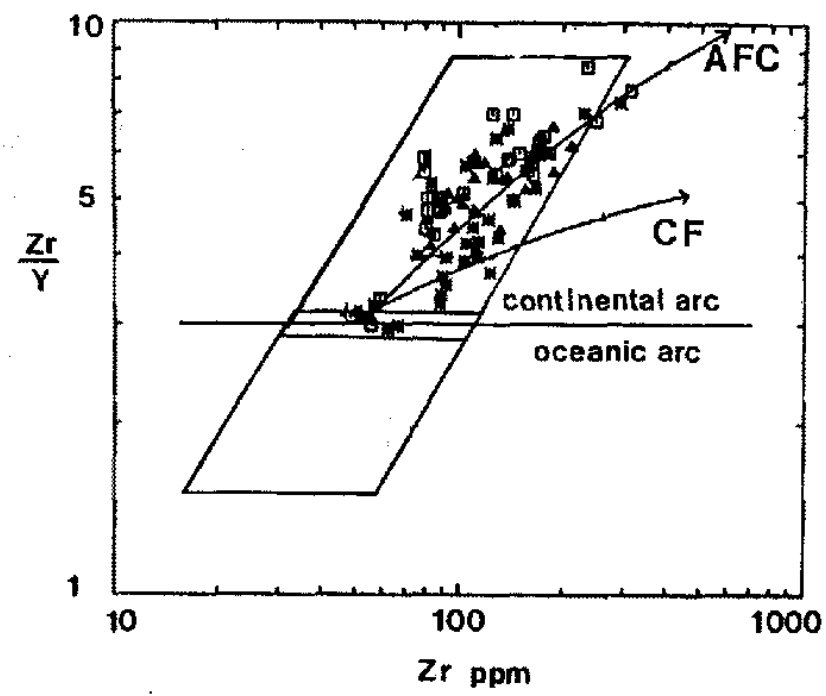

* Dikes

B.W. Greenstones

(0) Hemlock Volcanics

Fig. 7. $\mathrm{Zr} / \mathrm{Y}$ vs. $\mathrm{Zr}$ diagram. Basalt field locations are taken from Pearce (1983). Line AFC marks the simulation of $\mathrm{AFC}$ differentiation path with assimilation ratio: $\mathrm{R}=0.4, \mathrm{OL}: \mathrm{CPX}: \mathrm{PL}=$ $0.05: 0.65: 0.3$. Line $\mathrm{CF}$ marks the differentiation path of a crystal fractionation model.

grams whereas the LIL elements may be used with caution.

Several discrimination schemes utilizing distinctive immobile element distributions in mafic volcanics have been proposed to aid in the reconstruction of ancient tectonic settings. The application of such schemes to volcanic rocks of Precambrian age is based on the assumption that the ancient and modern magma genesis are basically the same.

a) Ti-Zr: Fig. 5 is a plot of $\mathrm{Ti}$ vs $\mathrm{Zr}$ used by Pharaoh and Pearce (1984). The purposes of this diagram are 1) to identify which samples are basic and thus able to be classified by basalt discrimination diagrams ; and 2) to dis. tinguish between a volcanic arc and a intraplate origin for the rocks. This diagram discriminates between basic and evolved lavas because the dominant crystallizing phases in basic magma (i.e., olivine, pyroxene, plagioclase) have insignificant effects in the $\mathrm{Ti} / \mathrm{Zr}$ ratio of the melt. However, when a $\mathrm{Ti}$ bearing phase begins to crystallize and the melt evolves from basic to acid, the removal of $\mathrm{Ti}$ results in a decrease in the $\mathrm{Ti} / \mathrm{Zr}$ ratio (Watters and Pearce, 1987). In Fig. 5, it is apparent that all the rocks fall in the basic lava side and that the most of the rocks plat in the within-plate basalt (WPB) and MORB fields.

b) Ti-Zr-Y: Fig. 6 is a plot of Ti-Zr-Y (Pearce and Cann, 1973) to distinguish within plate basalt (WPB), ocean-floor basalt (OFB), low-K tholeiite (LKT), and calc-alkaline basalt (CAB). The WPB affinity of the rocks is a dominant feature of the plot. However, a fairly large number of rocks plot in the OFB, LKT, and CAB fields. Although it do not provide a definite seperation of basalt type, this kind of pattern has been interpreted by Mor. rison (1978) and Holm (1982) as representative of incipient spreading within continental crust.

c) $\mathrm{Zr} / \mathrm{Y}-\mathrm{Zr}:$ Fig. 7 is a $\log$ plot of $\mathrm{Zr} / \mathrm{Y}$ $\mathrm{Zr}$ (Pearce, 1983). It effectively distinguishes between continental arc and oceanic arc basalts. The studied rocks cluster mainly in the continental arc field.

d) $\mathrm{La} / \mathrm{Nb}$ ratio histogram: It is difficult to chemically distinguish continental flood 
basalts (CFB) and ocean island basalts (OIB) with respect to degree of enrichment of overall elements. Both are enriched in LIL and HFS elements (Thompson et al., 1983). However, they show a difference in the concentration of $\mathrm{Nb}$. Histograms of $\mathrm{La} / \mathrm{Nb}$ ratio for examples of OIB, CFB, and subduction related basalts (IAB) are cited from Thompson et al. (1983) and given in Fig. 8a. Although this discriminant alone is insufficient to determine the paleotectonic environment of a single sample, it is adequate to distinguish between $\mathrm{CFB}, \mathrm{OIB}$, and IAB. The basaltic rock groups from the study area (Fig. 8 b) resemble the continental flood (CFB) basalts in regard to the $\mathrm{La} / \mathrm{Nb}$.

Most of the rocks from the study area plot in either the WPB field or the MORB field in figures 5,6 , and 7 . Of particular interest is that the less evolved rocks plot in the MORB field, while evolved rocks show a trend into the WPB field as seen in the $\mathrm{Zr} / \mathrm{Y}$ vs $\mathrm{Zr}$ plot. Although these diagrams do not provide a separation of normal MORB ( $\mathrm{N}$-type) and enriched type MORB (E-type), the chemical compositions of the least evolved samples $(\mathrm{Zr} / \mathrm{Nb}=6.1 \sim 15.6$, $\mathrm{Y} / \mathrm{Nb}=1.1-4.0$ ) are similar to that of transitional type MORB (T-type: $\mathrm{Zr} / \mathrm{Nb}=7.7-11.8$, $\mathrm{Y} / \mathrm{Nb}=1.3-3.0$; data from LeRoex et al., 1983). The $\mathrm{Zr} / \mathrm{Y}$ vs $\mathrm{Zr}$ plot show two possible differentiation paths; one is the Rayleigh crys. tal fractionation path (CF) and the other is assimilation fractional crystallization path (AFC) by using the equation of DePaolo (1981). $\mathrm{Zr} / \mathrm{Y}$ ratio of the supracrustal rocks (10; data from Ueng et al, 1988) are much higher than most of the basaltic rocks of this study. Thus, contamination of the supracrustal material could significantly raise $\mathrm{Zr} / \mathrm{Y}$ ratios of the magma during differentiation. In spider plots of suite averages (Fig. 10a) are distinctively depleted in $\mathrm{Nb}$ with respect to its neighboring elements. This depletion would require a mineral that selectively removes $\mathrm{Nb}$

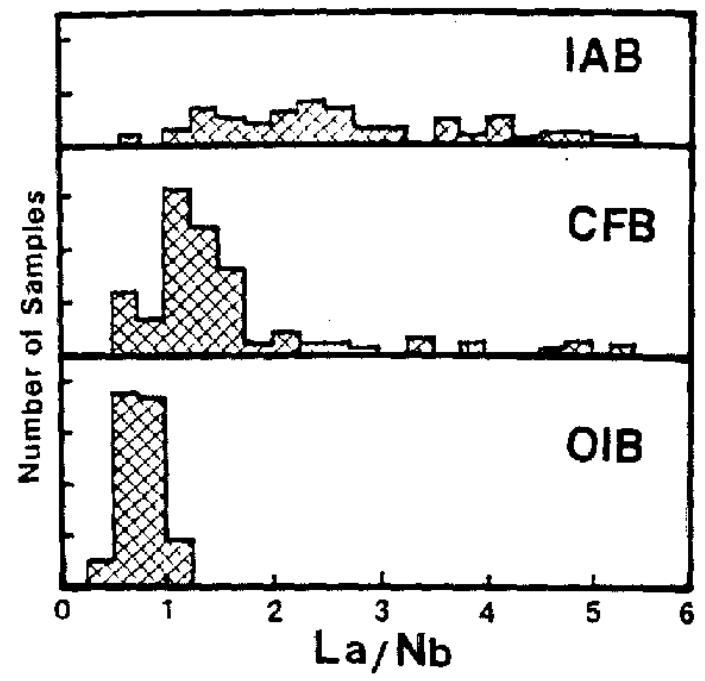

[a]
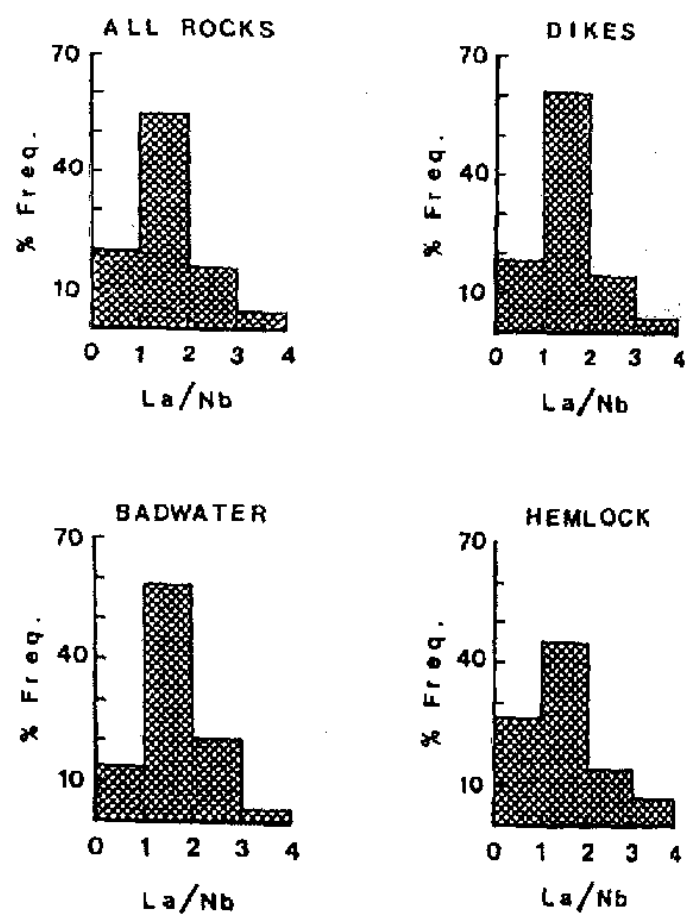

[b]

Fig. 8. Histogram of percent frequency vs. La/Nb. a) Histogram for island-arc basalts (IAB), continental flood basalts (CFB), and oceanic island basalts (OIB) (from Thompson et al., 1983). b) Histogram for the investigated rock suites. 


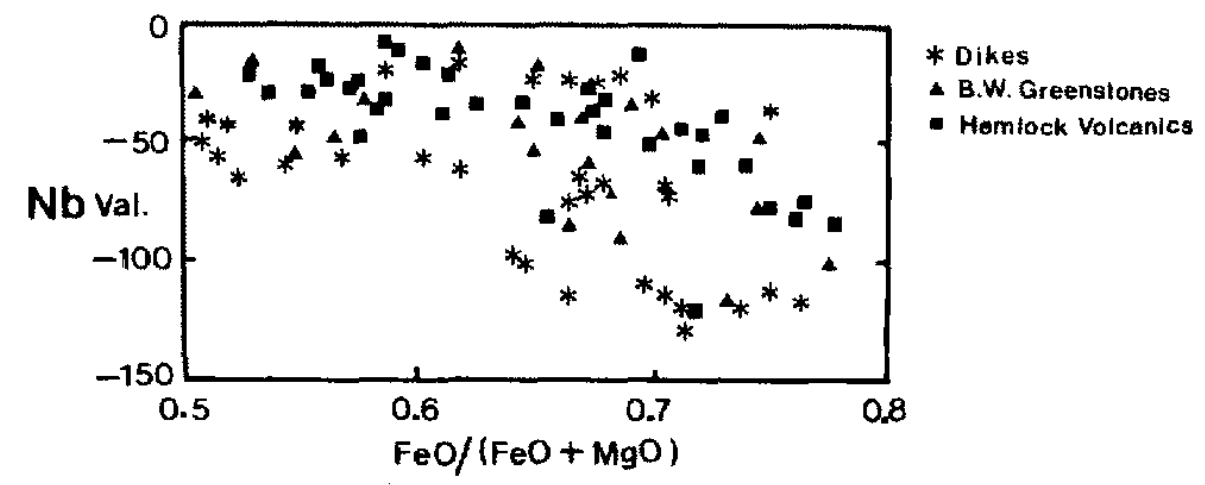

Fig. 9. Plot of $\mathrm{Nb}$ values vs. differentiation index $(\mathrm{Feo} /(\mathrm{FeO}+\mathrm{MgO})$ ) for the studied rocks. Nb value is defined as the difference between chondrite normalized $\mathrm{Nb}$ abundance and the average of chondrite normalized Th and La. Nb value $=\mathrm{Nb}_{\text {chon }} . \cdots\left(\mathrm{Th}_{\text {chon }}+\mathrm{La}_{\text {chon }}.\right) / 2$

with respect to other incompatible elements such as Th and La. Although $\mathrm{Nb}$ partitions strongly into the Ti-rich minerals such as sphene and rutile (Green and Pearson, 1987), there is no correlation between calculated $\mathrm{Nb}$ values $\left((\mathrm{Nb})_{\mathrm{c}}-\left[(\mathrm{Th})_{\mathrm{c}}+(\mathrm{La})_{\mathrm{c}}\right] / 2\right)$ and $\mathrm{Ti}$ content. Therefore, the depletion of $\mathrm{Nb}$ reflects the contamination of the magma by $\mathrm{Nb}$ depleted crustal rocks. Nb values (Fig. 9) for the dikes, the Hemlock volcanics, and Badwater greenstones decrease with increasing differentiation index. This implies continuing assimilation throughout the differentiation his. tory. Thus, these diagrams can be interpreted that trace element distributions are related to AFC processes and that the primary magma of the dikes, the Hemlock volcanics, and the Badwater greenstones are chemically not significantly different from $\mathrm{T}$-type MORB.

Fig. 10 illustrates some typical patterns of modern suites of continental tholeiitic basalts erupted in areas of lithospheric attenuation and rocks from the study area. The geochemical patterns of the rocks from the study area have very similar distribution patterns and resemble the continental tholeiitic basalts in regard to the degree of enrichment of LIL/HFS elements and $\mathrm{Nb}, \mathrm{P}$ depletion. The interpretation of these data strongly favor a model of magmatic intrusion into a crustal environment undergoing lithospheric attenuation.

\section{Discussion}

In this study, three possible tectonic models were considered; 1) subduction related plate margin model (Van Schmus, 1976), 2) rifting of passive continental margin model (Cambray, 1978), and 3) foredeep model (Hoffman, 1988).

In the subduction related plate margin model (Van Schmus, 1976), the study area represents a back arc or foreland basin assem blage. According to his model, the magma that supplied the dikes and the flows should be related to arc volcanism. However, the geochemical characteristics of the rock suites are unlike those of arc volcanism (Fig. 3 and 6). Thus, the subduction related plate margin model can not be supported by the chemical characteristics of the rock suites.

The foredeep model (Hoffman, 1988) interpreted these volcanics as a product of foredeep magmatism similar to the Taiwan Strait, the Persian-Arabian Gulf, and the Ganges River basin. Hoffman (1988) suggested that flexural response of continental lithosphere due to loading of thrust sheet during arc-continent collision induced magma generation in the foredeep. Because the magma generated in this model 


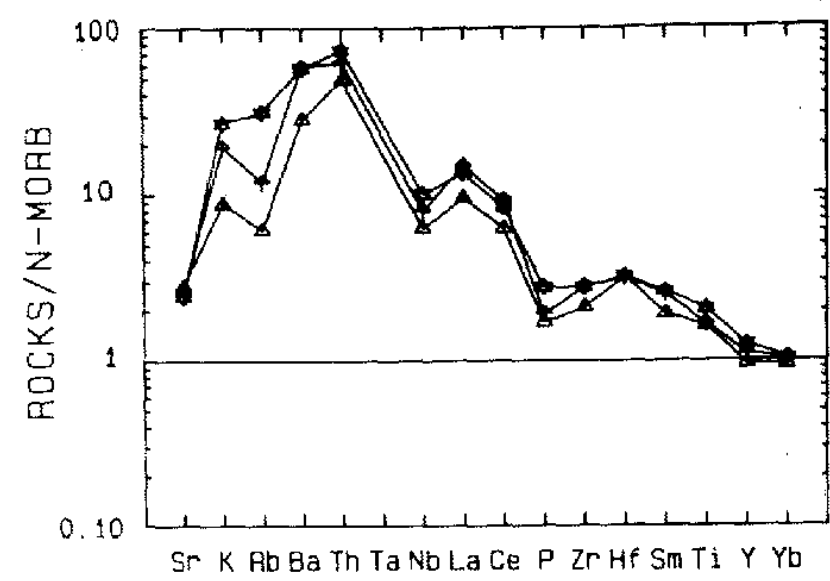

* DIKES

* HEMLOCK VOLCANICS

$\triangle$ B.W. GREENSTONES

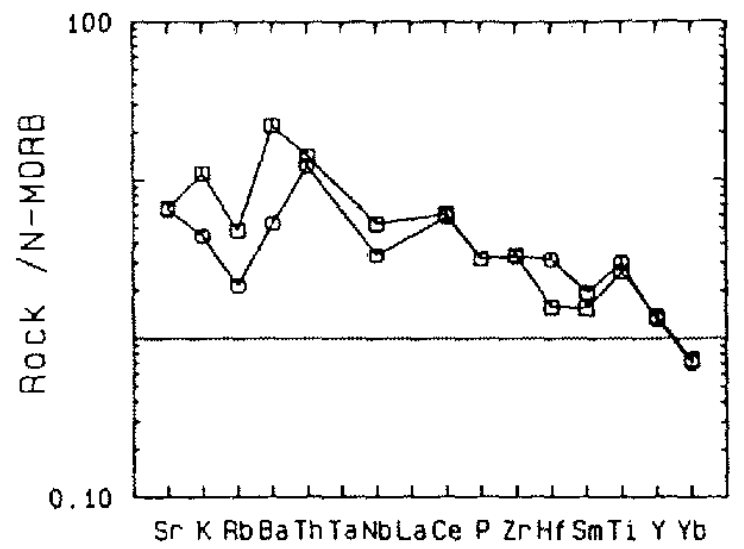

D BTVp (Skye lava)

O BTvp (mull lava)

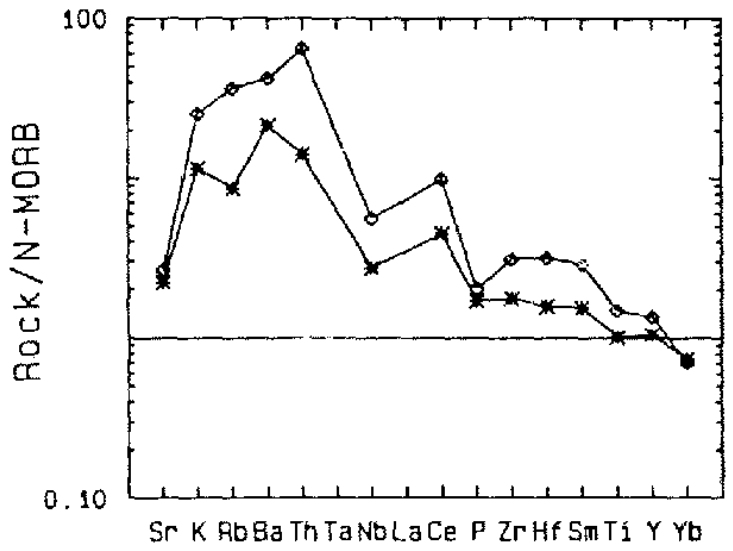

* Lesotho (CTB)

- Etendeka (CTB)

Fig. 10. Geochemical patterns of basalts from the study area and known tectonic environments normalized to $\mathrm{N}$-type MORB (from Viereck et al., in press). Data sources for Figure 10b from Thompson (1982), and Peccerillo and Taylor (1976). BTVP: British Tertiary Vol. canic Province, CTB : continental tholeistic basalt 
Table. 1. Average chemical compositions of the rock suites

\begin{tabular}{|c|c|c|c|c|c|c|c|c|c|}
\hline & \multicolumn{9}{|c|}{ (Feo reprosunts total Iron) } \\
\hline & \multicolumn{3}{|c|}{$\begin{array}{l}\text { Dikes } \\
(N=44)\end{array}$} & \multicolumn{3}{|c|}{$\begin{array}{l}\text { Hemlock volcanics } \\
\qquad(\mathrm{N}=40)\end{array}$} & \multicolumn{3}{|c|}{$\begin{array}{l}\text { Badwater greenstones } \\
\qquad(\mathrm{N}=29)\end{array}$} \\
\hline & Mean & Range & C. V. & Mean & Range & C.V. & Mean & Range & C.v. \\
\hline $\mathrm{SiO}_{2}$ & 49.58 & $44.98-55.03$ & 4.1 & 50.36 & $45.34-60.02$ & 7.1 & 49.16 & $43.71-52.50$ & 4.8 \\
\hline $\mathrm{Al}_{2} \mathrm{O}_{3}$ & 14.04 & $12.44-17.33$ & 8.6 & 14.55 & 11. $82-18.17$ & 10.9 & 15.30 & $12.54-20.99$ & 10.9 \\
\hline$F \in 0^{*}$ & 13.01 & $9.30-16.67$ & 14.5 & 11.86 & $6.56-14.66$ & 17.5 & 11.74 & $7.43-15.35$ & 15.5 \\
\hline $\mathrm{MnO}$ & 0.20 & $0.13-0.26$ & 14.7 & 0.18 & $0.08-0.22$ & 17.1 & 0.18 & $0.13-0.25$ & 13.8 \\
\hline $\mathrm{MgO}$ & 6.54 & $2.46-11.64$ & 30.1 & 6.33 & $2.25-10.72$ & 32.5 & 6.18 & $3.62-9.51$ & 22.6 \\
\hline $\mathrm{CaO}$ & 7.84 & $3.39-11.28$ & 26.7 & 8.00 & $3.17-11.00$ & 26.8 & 9.24 & $4.26-16.95$ & 28.9 \\
\hline $\mathrm{Na}_{2} \mathrm{O}$ & 2.58 & $1.46-4.48$ & 29.0 & 2.88 & $1.28-5.52$ & 34.7 & 2.37 & $0.29-5.16$ & 41.9 \\
\hline $\mathrm{K}_{2} \mathrm{O}$ & 1.12 & $0.31-2.26$ & 43.9 & 0.90 & $0.12-2.84$ & 75.6 & 0.52 & $0.04-1.86$ & 86.4 \\
\hline $\mathrm{TiO}_{2}$ & 1.69 & $0.63-2.83$ & 37.9 & 1.46 & $0.84-2.62$ & 35.9 & 1.53 & $0.97-2.54$ & 26.1 \\
\hline $\mathbb{P}_{2} 0_{5}$ & 0.24 & $0.04-1.33$ & 117.4 & 0.16 & $0.06-0.43$ & 50.0 & 0.16 & $0.10-0.30$ & 35.0 \\
\hline $\mathrm{Ni}$ & 81.1 & $0.0-440.3$ & 97.4 & 72.0 & $3.3-218.4$ & 83.5 & 105.7 & $24.4-280.8$ & 72.7 \\
\hline $\mathrm{Cu}$ & 80.9 & $7.5-228.4$ & 77.3 & 61.5 & $1.5-136.9$ & 68.6 & 106.3 & $0.1-248.0$ & 57.1 \\
\hline $\mathrm{Cr}$ & 182.9 & $40.5-603.0$ & 72.4 & 134.8 & $5.1-470.9$ & 95.6 & 190.4 & $22.3-368.1$ & 53.4 \\
\hline $\mathrm{Zn}$ & 107.4 & $57.2-165.0$ & 21.0 & 100.1 & $59.6-200.2$ & 25.7 & 93.8 & $62.2-127.6$ & 19.3 \\
\hline $\mathrm{Rb}$ & 31.2 & $1.6-101.4$ & 63.9 & 12.9 & $0.0-\quad 38.4$ & 79.3 & 8.3 & $0.0-37.8$ & 110.9 \\
\hline $\mathrm{Sr}$ & 218.1 & $62.7-516.0$ & 44.6 & 239.9 & $56.1-920.2$ & 72.1 & 256.0 & $115.3-524.0$ & 40.7 \\
\hline $\mathrm{Y}$ & 26.7 & $14.9-55.3$ & 35.3 & 23.9 & $13.4-61.5$ & 39.4 & 22.6 & $17.4-34.2$ & 21,6 \\
\hline $\mathrm{Sc}$ & 37.0 & $19.3-50.6$ & 17.1 & 34.6 & $15.8-52.9$ & 24.8 & 37.7 & $27.0-\quad 50.7$ & 15.7 \\
\hline $\mathrm{Zr}$ & 138.2 & $50.1-288.5$ & 65.1 & 143.9 & $48.4-563.3$ & 68.6 & 118.8 & $78.2-210.9$ & 29.4 \\
\hline $\mathrm{Nb}$ & 17.1 & $2.8-68.7$ & 116.4 & 14.1 & $1.0-72.7$ & 90.4 & 12.0 & $4.0-25.8$ & 43.6 \\
\hline $\mathrm{Ba}$ & 393.3 & $18.6-2008.0$ & 93.5 & 438.0 & $0.0-4145.0$ & 163.0 & 253.1 & $30.4-1340.0$ & 119.9 \\
\hline La & 20.84 & $4.64-46.40$ & 90.9 & 23.76 & $4.00-187.91$ & 134.4 & 16.21 & $8.76-40.88$ & 48.2 \\
\hline $\mathrm{Ce}$ & 40.62 & $9.58-101.26$ & 99.3 & 49.23 & $18.29-275.20$ & 95.5 & 34.67 & $19.98-102.50$ & 52,3 \\
\hline Si & 5,15 & $1.37-9.18$ & 63.7 & 5.11 & $1.00-24.78$ & 83.8 & 4.12 & $0.75-7.70$ & 37.4 \\
\hline Eu & 2.03 & $0.90-4.12$ & 53.7 & 1.66 & $0.81-\quad 5.28$ & 52.4 & 1.87 & $0.99-2.94$ & 30.5 \\
\hline $\mathrm{Tb}$ & 0.80 & $0.34-1.14$ & 23.7 & 0.70 & $0.32-1.15$ & 29.0 & 0.70 & $0.40-1.02$ & 22.2 \\
\hline $\mathrm{Yb}$ & 2.44 & $1.48-3.06$ & 13,7 & 2.37 & $1.47-15.13$ & 43.9 & 2.27 & $1.72-2.91$ & 121.4 \\
\hline Lu & 0.40 & $0.19-0.52$ & 16.4 & 0.37 & $0.17-0.71$ & 27.0 & 0.37 & $0.13-0.45$ & 17.0 \\
\hline Hf & 4. 51 & $1.87-11.09$ & 53.0 & 4,42 & $1.47-15.73$ & 68.3 & 4.54 & $2.17-9.45$ & 44.4 \\
\hline $\mathrm{Th}$ & 6.72 & $1.42-11.80$ & 50.3 & 5.58 & $0.83-46.84$ & 142.5 & 4.64 & $1.83-11.85$ & 52.6 \\
\hline
\end{tabular}

C.V. $=$ coefficient of variation $[($ Standard Dev. $/$ Mean $) \times 100]$

will be crust-contaminated MORBs, this is a possible model to explain the evolution of the Baraga Group volcanism based on geochemical considerations. However, a mechanism initiating partial melting of subcontinental mantle in a foredeep model is still in doubt because the melting of mantle is dominated by adiabatic decompression (Allegre et al., 1982).

The rifting model (Cambray, 1978) suggest that the Chocolay Group strata were deposited in a cratonic setting and that the strata of the Menominee Group features are rift deposits. The geochemical patterns (Fig. 10a) are analogous to that of lavas from the British Tertiary Volcanic Province (BTVP in Fig. 9b; Skye and Mull lavas) that were generated during the opening of the North Atlantic Ocean (Brooks and Nielsen, 1982; Thompson, 1982), and to continental tholeiites from Edendeka in western Africa (Fig. 10b) that erupted in a rift 
environment related to the separation of south. ern Africa from South America (Duncan, 1987).

\section{Conclusions}

Despite the age and metamorphism of the studied rock suites, geochemical analysis has provided useful information to constrain the paleotectonic environment of the studied area. Most of the least evolved rock samples plot in the MORB field in tectonic discrimination diagrams, and these rocks are chemically similar to present day T-type MORB compositions. Also, the estimated magma source shows a relatively undepleted LREE/HREE pattern (Wee, 1992). Thus, with consideration of assimilation effects, the rocks of the study area were probably derived from a chemically $T$ type MORB-like, relatively undepleted, lithospheric upper mantle source. The relatively undepleted parent magma modified by $\mathrm{AFC}$ process for the studied rock suites and this process shifted the rock composition to that of continental tholeites as the rock evolved.

Based on the geochemical characteristics and tectonic discrimination diagrams, the studied rock suites are believed to have emplaced during rifting. The geochemical patterns of these rocks are similar to those of British Tertiary Volcanic Province and continental tholeiitic basalts from Edendeka, which erupted in more recent rift environments. Thus, the rifting model (Cambray, 1978) seems the most favourable to explain the tectonic evolution of the studied area.

Acknouledgements : I would like to thank my advisor, the late Dr. J.T. Wilband for all his help, encouragement and advice during the preparation of this study. I would give special thanks to Professors K. Fujita and T. Vogel of the Department of Geological Sciences, Michigan State University, Financial research grant for this study was provided by Chevron Oil Company and the Center for Mineral Resources Research sponsored by the Korea Science and Engineering Foundation.

\section{References}

Allegre, C.J., Dupre, B., Richard, P., Rosseau, D., and Brooks, C. (1982), Subcontinenta! versus suboceanic mantle, II. Eatth Planet. Sci. Lett., 57, 25-34.

Baxter, D.A. and Bornhorst, T.J. (1988), Multiple discrete mafic intrusions of Atchean to Keweenawan age, western Upper Peninsula, Michigan. (abstr.) 34th Ann. Inst. Lake Supe rior Geol., Marquette, Michigan, 6-8.

Brooks, C.K. and Nielsen, T.F.D. (1982), The E. Greenland continental margins; a transition of continental to oceanic volcanism. J. Geol. Soc. London, 139, 265-275.

Cambray, F.W. (1977), The geology of the Marquette district. A field guide, Michigan Basin Geol. Soc., pp. 62

Cambray, F.W. (1978), Plate tectonics as a model for the environment of deposition and deformation of the early Proterozoic (Precambrian $\mathrm{X}$ ) of northern Michigan. Geol. Soc. Amer. Abst. w/Prog., 10, no. 7, 376 .

Cambray, F.W. (1984), Proterozoic geology Lake Superior, A field guide. Geol. Asso. Canada, pp. 55

Cann, J.R. (1970), Rb, Sr, Y, Zr and $\mathrm{Nb}$ in some ocean-floor basaltic rocks. Earth Planet. Sci. Lett., 10, 7-11.

Cannon, W.F. (1973), The Penokean Orogeny in Northern Michigan. Geol. Assoc. Canadi, Spec. Pap., 12, 251-271.

Cannon, W.F. and Klasner, J.S. (1976), Geologic map and geophysical interpretation of the Witch Lake quadrangle, Marquette, Iron, and Baraga counties, Michigan. Misc. Geol. lnvest. Map I-987

Cudzilo, T.F. (1978), Geochemistry of early Proterozoic igneous rocks northeastem Wis consin and upper Michigan. Ph.D. Thesis, University of Kansas, pp. 202

DePaolo, D.J. (1981), Trace element and isotopic effects of combined wallrock assimilation and fractional crystallization. Earth Planet Sci. Lett., 53, 189-202.

Duncan, A.R. (1987), The Karoo igneous province; a problem area for inferring tectonic setting from basalt geochemistry. J. Volcanol. Geoth 
erm. Res. 32, 13-34.

Ferrara, G., Innocenti, F., Ricci, C.A. and Serri, G. (1976), Ocean-foor affnity of basalts from north Apennine ophiolites: geochemical evidence. Chem. Geal., 17, 101-111.

Floyd, P.A. and Winchester, J.A. (1975), Magma type and tectonic setting discrimination using immobile elements. Earth. Planet. Sci. Lett., 27, 211-218.

Fox, T.P. (1983), Geochemistry of the Hemlock metabasalt and Kiernan sills, Iron county, Michigan. unpublished M.S. Thesis, Michigan State Univ., pp. 81

Gaskarth, J.W. and Parslow, G.R. (1987), Proterozoic voclanism in the Flin Flon greenstone belt, east central Sakatchewan, Canada. Geol. Soc. Spec. Publ., 33, 183-200.

Gelinas, L., Mellinger, M. and Trudel, P. (1982), Archean mafic metavolcarics from the - Rouyn-Noranda district, Abitibi Greenstone belt, Quebec. 1. Mobility of the major elements. Can. J. Earth Sci. 19, 2258-2275.

Hoffman, P.F. (1988), Animikie Group: A .Penonean Foredeep?.(abstr.) 34th Ann. Inst. Lake Superior Geol., Marquette, Michigan, 4041.

Holm, P.E. (1982), Non-recognition of continental tholeites using the $\mathrm{Ti}-\mathrm{Zr}-\mathrm{Y}$ diagram. Contrib. Mineral. Petrol, 79, 308-310.

Honkamo, M. (1987), Geochemistry and tectonic setting of early Proterozoic volcanic rocks in northern Ostrobothnia, Finland. Geol. Soc. Spec. Publ., 33, 59-68.

Hughes, C.J. (1973), Spilites, Keratophyres, and the Igneous spectrum. Geol. Mag., 109, 513527.

Humphris, S.E. and Thompson, G. (1978), Trace element mobility during hydrothermal alteration of oceanic basalts. Geochim. Cosmochim. Acta, 42, 127-136.

James, H.L., Dutton, C.E., Pettijohn, F.J. and Weir, K. (1968), Geology and ore deposits of the Iron River-Crystal Falls district, Iron county, Michigan. U. S. Geol. Surv. Prof. Pap., 570, pp. 134

Klasner, J.S. (1978), Penokean deformation and associated metamorphism in the western Marquette Range, northern Michigan. Geol. Soc. Amer. Bull., 89, 711-722.

Knoper, M.W. and Condie, K.C. (1988), Geochemistry and petrogenesis of early Proterozoic amphibolites west-central Colorado, U.S.A. Chem. Geol., 67, 209-225.

Larue, D.K. (1983), Early Proterozoic tectonics of the Lake Superior region: Tectonostratigraphic terrane near the purported collision zone. Geol. Soc. Amer. Memor. 160, 33-47.

Larue, D.K. and Sloss, L.L. (1980), Early Proterozoic sedimentary basins of the Lake Superior region: Summary. Geol. Sac. Amer. Bull. Part 1, 91, 450-452.

Larue, D.K. and Leng, W.L. (1985), FlorenceNiagara terrane, an early Proterozoic accretionary complex, Lake Superior region, $U$. S.A.. Geol. Soc. Amer. Bull, 96, 1179-1187.

LeRoex, A.P., Dick, H.J.B., Erlank, A.J., Reid, A. M., Frey, F.A. and Hart, S.R. (1983), Geochemistry, mineralogy and petrogenesis of lavas erupted along the southwest Indian ridge between the Bouvet triple junction and 11 degree east. J. Petrol. 24, part 3, 267-318.

Ludden, J.N., Gelinas, L. and Trudel, P. (1982), Archean metavolcanics from the Rouyn-Noranda district, Abitibi greenstone belt, Qubec. 2. Mobility of trace element and petrogenetic constraints. Can. J. Earth Sci., 19, 2276-2287.

Ludden, J.N. and Thompson, G. (1978), Behavior of rare earth elements during submarine weathering of sea-floor basalt. Earth Planet. Sci: Lett., 43, 85-92.

Marsh, J.S. (1987), Basalt geochemistry and tectonic discrimination within continetal flood basalt provinces. J. Volcanol. Geotherm. Res., $32,35-49$.

Morrison, M.A. (1978), The use of immobile elements to distinguish the paleotectonic affinities of metabasalts: application to Paleocene basalts of Mull and Skye, N.W. Scotland. Earth Planet. Sci. Lett., 39, 407-416.

Muecke, G.K, Pride, C. and Sarkar, P. (1979), Rare earth element geochemistry of regional metamorphic rocks, In Origin and distribution of the elements (Ahrens, L.H., Ed). Pergamon Press, Elmsford, N.Y., 449-464.

Pearce, J.A and Cann, J.R. (1973), Tectonic setting of basic volcanic rocks determining using trace element analyses. Earth Planet. Sci. Lett., 19, 290-300.

Pearce, J.A. and Norry, M.J. (1979), Petrogenetic implications of $\mathrm{T} i, \mathrm{Sr}, \mathrm{Y}$ and $\mathrm{Nb}$ variations in volcanic rocks. Contrib. Mineral. Petrol., 69, $33-47$.

Peccerillo, A. and Taylor, S.R. (1976), Geochemistry of Eocene calc-alkaline volcanic rocks from the Kastsmonu area, northern Turkey. Contrib. Mineral. Petrol., 58, 63-81.

Pharaoh, T.C. and Pearce, J.A. (1984), Geochemical evidence for the geotectonic setting 
of early Proterozoic metavolcanic sequences in Lapland. Precambrian Res., 25, 283-308.

Sims, P.K. (1976), Precambrian tectonics and mineral deposits, Lake Superior region. Econ. Geol., 71, 1092-1127.

Sims, P.K. (1980), Boundary between Archean greenstone and gneiss terranes in nothern Wisconsin and Michigan. Geol. Soc. Spec. Publ., 182, 113-124.

Sims, P.K. (1988), Evolution of the early Protero. zoic Wisconsin magmatic terrane of the Peno. kean Orogeny, (abstr.), 34th Ann. Inst. Lake Superior Geol., Marquette, Michigan, 100.

Sun, S.S. and Nesbitt, R.W. (1978), Geochemical regularities and genetic significance of ophiolitic basalts. Geol., 6, 689-693.

Thompson, R.N. (1982), Magmatism of the British Tertiary Volcanic Province. Scottish J. Geol., 18, I- 108 .

Thompson, R.N., Morrison, M.A., Dickin, A.P. and Hendry, G.L. (1983), Continetal flood basalt Arachnids Rule OK?. In Continental basalts and mantle xenoliths (Hawkesworth, C.J. and Norry, M.J., Eds). Shiva Publishing Ltd. Nantwich, U.K., 158-185.

Ueng, W.C., Fox, T.P., Larue, D.K. and Wilband, J. T. (1988), Geochemistry and petrogenesis of the early Proterozoic Hemlock volcanic rocks and the Kiernan sills, southern Lake Superior region. Can. J. Earth Sci., 25, 528-546.

Van Schmus, W.R. (1976), Early and middle Proterozoic history of the Great Lake area, North America. Phil. Trans. Royal Soc. Lon. don, Ser. A, 280, 605-628.

Viereck, L.G., Flower, M.F.J., Hertogen, J. and Schmincke, H.U., The genesis and significance of N-MORBs. Contrib. Mineral. Petrol., (in press)

Watters, B.R. and Pearce, J.A. (1987), Metavol. canic rocks of the La Ronge Domain in the Churchill Province, Saskatatchewan: geo. chemical evidence for a volcanic arc origin. Geol. Soc. Spec. Pub., 33, 167-182.

Wee, S.M. (1989), Geochemical investigation of early Proterozoic igneous rocks in northern Michigan and the northeast portion of Wisconsin, U.S.A. Ph.I Thesis, Michigan State Univ., pp. 385

Wee, S.M. (1992), Geochemistry and petrogenesis of early Proterozoic dikes and metabasalts from the southern Lake Superior region. I. Geol. Soc: Korea, 28, no. 1, 52-72.

Wood, D.A., Gibson, I.L. and Thompson, R.N. (1976), Elemental mobility during zeolite facies metamorphism of the Tertiary basalts of eastern Iceland. Contrib. Mineval. Petrol., 55, 241-254. 